UDC 070:659.1]:553.7:615.38] (477)

DOI https://doi.org/10.24919/2308-4863/34-4-19

\author{
Oksana ROHACH, \\ orcid.org/0000-0002-5304-0837 \\ Candidate of Philological Sciences, \\ Associate Professor at the Department of Applied Linguistics \\ Lesya Ukrainka Volyn National University \\ (Lutsk,Ukraine)oksanarog@vnu.edu.ua
}

Yulia ROGACH, orcid.org/0000-0002-5769-6948

Candidate of Philological Sciences,

Senior Lecturer at the Department of Applied Linguistics

Lesya Ukrainka Volyn National University

(Lutsk,Ukraine)rogach.yulia@vnu.edu.ua

\title{
MULTIMODAL PECULIARITIES OF PRINTED ADVERTISEMENTS OF MINERAL WATER IN UKRAINE
}

The article is devoted to the analysis of multimodal advertisements which play a very important role in the modern social, business, and mass-media communication. As the means of creating advertisements are constantly changing our task is to analyze the structure and semantics of the advertisements of mineral water in the Ukrainian mass-media and business discourse. In the historical aspect, advertisement can be characterized as a targeted tool that is used by a manufacturer or a seller of a product in order to influence a consumer and raise the sale levels. It was pointed out that the main purpose of the advertisements is to attract the customers' attention, make them think and change their thoughts and/or behaviour. Due to the synchronic usage of different communicative modes and visual tools, modern printed advertisements are complex and multimodal, consisting of verbal and non-verbal elements. The application of verbal and non-verbal elements in an advertisement allows scholars to classify it as a multimodal text. Non-verbal elements are present in almost every printed advertisement. The following non-verbal means have been distinguished: images, pictures, schemes, logos, sketches, national symbols, fonts'types and sizes, colour choices, position, location, and design of a verbal text in an advertisement, etc. Visual images, typically, play a major role in the creation of the modern language consciousness, because a visual perception is universal and it is able to integrate and reintegrate any other systems of signals. Non-verbal means acquire a special importance, forming together with a verbal part the contextual and pragmatic meaning of the advertisement. Non-verbal means, correlating with the verbal elements, either intensify, or repeat and complete the meaning of the verbal messages. The variations of fonts (cursive, underlined, bold), sizes of letters, their capitalization and colouring help to make the texts bright, eye-catching, and memorable. In the analyzed examples, the majority of copywriters used the images of mountains and natural water to demonstrate the purity and freshness of their product. It was stated that as such advertisements were created to promote a very popular and essential product - mineral water, they are national, direct, lightly or medium segmented and commercial.

Key words: multimodality, advertisement, mineral water, verbal means, non-verbal means, correlation, promotion, colour. 
Rohach O., Rogach Y. Multimodal peculiarities of printed advertisements of mineral ...

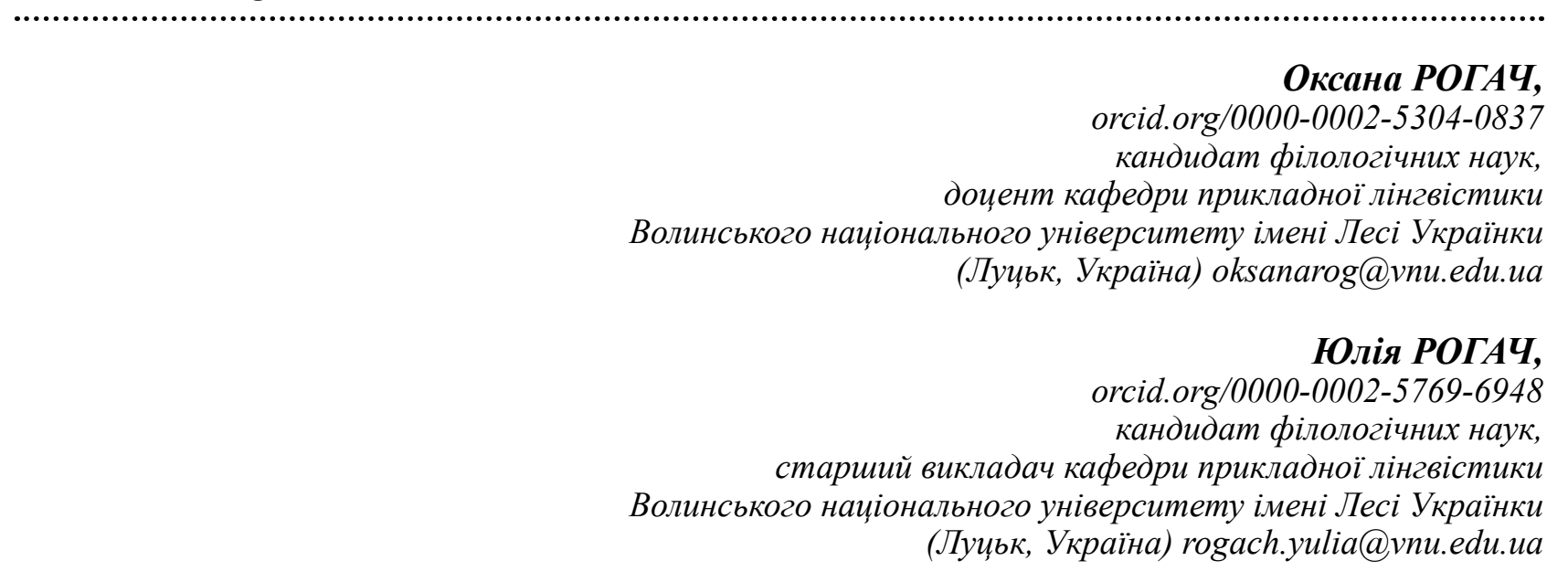

\title{
МУЛЬТИМОДАЛЬНІ ОСОБЛИВОСІ ДРУКОВАНОЇ РЕКЛАМИ МІНЕРАЛЬНОЇ ВОДИ В УКРАЇНІ
}

\begin{abstract}
Стаття присвячена аналізу мультимодальної реклами, яка відіграє важливу роль у сучасній сочіальній, діловій та масмедійній комунікації. Виходячи з того, щуо засоби створення реклами зазнають постійних змін, наме завдання - проаналізувати структуру та семантику рекламних оголошень мінеральної води в украӥнському масмедійному та бізнесовому дискурсі. У своїй тенезі рекламу можна представити як иільовий інструмент, який використовують виробники чи продавці продукту з метою впливу на споживача, а також для підняття рівнів продажів. Було встановлено, щуо головне завдання реклами полягає у привертанні уваги споживачів з тією метою, щьоб надалі заставити їх задуматися та змінити їхні думки чи/та поведінку. Завдяки використанню різноманітних комунікативних модусів та візуальних інструментів сучасна реклама є комплексною та мультимодальною і складається з вербальних та невербальних компонентів. Синхронне застосування вербальних та невербальних засобів у рекламному оголошенні дає можливість науковцям класифікувати його як мультимодальний текст. Невербальні засоби присутні майже в усіх друкованих рекламних оголошеннях. У мультимодальній рекламі виокремлюють такі найуживанімі невербальні засоби, як: зображення, картинки, схеми, національні символи, типи шрифтів та їхні розміри, вибір кольору, розміщення, локація, а також дизайн вербального тексту та ін. Візуальні зображення зазвичай відіграють основну роль у створенні сучасної мовної свідомості, оскільки візуальне сприйняття - універсальне та здатне інтегрувати та реінтегрувати будь-які інші системи сигналів. Невербальні засоби набувають особливої значимості, створюючи разом з вербальною частиною контекстуальне та прагматичне значення рекламного оголошення. Невербальні засоби в кореляції з вербальними елементами підсилюють чи доповнюють значення вербальної частини повідомлення. Варіації шрифтових фонтів (курсив, підкреслення), зміни розмірів букв, їхн капіталізація та інший колір допомагають зробити тексти яскравими, захоплюючими та такими, щчо запам'ятовуються. Дослідження показало, щяо в прикладах, які були проаналізовані, більшість копірайтерів використовували зображення гір та води для демонстрації чистоти та свіжості рекламованого продукту. Було встановлено, щчо оскільки ичі рекламні оголошення були створені для промоції такого дуже популярного та важливого продукту, як мінеральна вода, то за своєю природою їх можна вважати національними, прямими, легко-чи середньо-сегментованими та комериійними.
\end{abstract}

Ключові слова: мультимодальність, мінеральна вода, реклама, вербальні засоби, невербальні засоби, кореляція, промочія, колір.

The scientific problem statement. Nowadays advertisements play a very important a role in the life of any social community, influence its business, social and cultural spheres, and very often shape its cultural values and beliefs. They are integrated parts of mass-media discourse which play a very important role in the modern social, business, and mass-media communication. Advertisements are to be well-structured, designed and well-presented as their main purpose is to attract the customers' attention, make them think and change their thoughts and/or behavior. Due to the usage of different communicative modes and visual tools, modern printed advertisements are complex and multimodal, consisting of verbal and non-verbal elements. In the historical aspect, advertisement can be characterized as a targeted tool that is used by a manufacturer or a seller in order to influence a consumer and raise the sale levels (Поляков, 2006). The means and units that are used in advertisements are constantly changing, taking new forms and combinations which, in its turn, requires the attention of scholars and new approaches to their studies. Being very powerful, influential and manipulative, advertisements must be thoroughly analyzed, processed, and understood.

The analysis of the conducted studies. There are many scholars who devoted their works to the studies of modern multimodal advertisements: R. Bart, 
P. Messaris, D. Bezlatnyi, I. Morozova, N. Liutianska, V. Poliakov, N. Valgina, N. Skukalenko, and others. Such topics as the semantic and grammatical structures of multimodal advertisements, the correlation of verbal and non-verbal parts, means of achieving pragmatic, aesthetic, and manipulative effects have become the centers of their scientific interests. In spite of that, multimodal advertisements of mineral water have not been analyzed from the mentioned above multi-dimensional vectors, so they need a detailed scientific analysis.

The purpose of the article is to conduct a comparative analysis of the multimodal advertisements, devoted to the promotion of mineral water in Ukraine, to find out its structural, semantic and pragmatic peculiarities, national coloring and cultural value. In order to achieve the purpose the following methods and approaches have been used: a discourse analysis, structural and descriptive methods, and a componential analysis.

Main body. A modern advertisement combines the propaganda and modern advances that have been achieved in the marketing field, in order to create an "ideal product". It is possible to claim that promotions of products or services have become less informative but more pragmatized and commercialized as well as manipulative. The peculiarities of advertisements are defined by their communicative and pragmatic goals that could be noticed through the special selection of verbal and non-verbal elements. If we talk about their pragmatic character, the main goal is to make a strong influence on a target audience which could be achieved via multiple channels such as rational thoughts and convincing, instincts as well as subconscious emotions.

The application of verbal and non-verbal elements in an advertisement allows scholars to classify it as a multimodal text. Non-verbal means acquire a special importance, forming together with a verbal part the contextual and pragmatic meaning of the advertisement. R. Bart (Bart, 2002) defined three types of correlation and connection between a text and an image/ picture/non-verbal element:

a) a text and a picture duplicate each other;

b) a text performs the major role, and the semantics of the picture depends upon it. We can say that a visual component is an addition to a verbal element;

c) a verbal component depends on the image.

$\mathrm{N}$. Valgina contends that the majority of multimodal texts follow a pattern when verbal and visual components are in synsemantic relationship (Valgina, 2003). This theory is similar to the third type of correlation, suggested by R. Bart, when an image defines the semantics of the verbal text.
Non-verbal elements are present in almost every printed advertisement. Scholars, who work in this field, point out the following non-verbal means: images, pictures, schemes, logos, sketches, national symbols, fonts' types and sizes, colour choices, position, location, and design of a verbal text in an advertisement, etc. Visual images, typically, play a major role in the creation of the modern language consciousness, because a visual perception is universal and it is able to integrate and reintegrate any other systems of signals (Skukalenko, 1992: 53-55).

The American scientist P. Messaris, while studying the peculiarities of visual persuasion in advertising and analyzing the role that visual elements play, asserts that images can provoke certain feelings by stimulating an appearance of a particular object or a person, can be a visual proof that something really happened, as well as install the implicit connection between an object, service or a thing that is being offered, and other images (Messaris, 1996). It is necessary to point out that means of multimodality define how an advertisement is going to be perceived. This gives extra importance to the information provided, defines the understanding of the message, a level of trust and influence that it has.

$\mathrm{N}$. Liutianska states that the main goal of an advertisement is to influence the consciousness of a consumer and to stimulate him/her to perform a certain action - to buy a particular item. The main task of advertising discourse is to convince the addressee in the honesty and authenticity of the message (Liutianska, 2014: 138).

According to I. Morozova, the core role in attracting the attention of the audience, is given to the slogans, that can modify verbal and physical behavior (Morozova, 2017). As printed advertisements are multifaceted phenomena that are targeted at a wide range of consumers, there are different types of their classification. D. Bezlatnyi defines 8 major categories of them: 1) according to the target audience - highly segmented, medium segmented, lightly segmented; 2 ) according to the targeted influence - commercial (goods and services), and non-commercial (political or social); 3) according to the scale of distribution global, national, regional and local; 4) according to the method of transmission - printed, electronic and outdoor advertising; 5) according to the way of execution - textual, visual and visually-textual; 6) according to the method of influence - direct and non-direct; 7) according to the method of addressing - personified and non-personified; 8) according to the method of payment - free and paid (Bezlatnyi, 2011).

Considering the suggested approaches, we have analyzed printed multimodal advertisements of mineral water in the Ukrainian mass-media discourse with 
the focus on their types, structure, usage of non-verbal elements and their correlation with the verbal ones.

The first advertisement (picture 1) was created by the company called Alex. No slogans or messages are seen in the picture; the only verbal elements are the names on the bottles and the logo of the company. The picture is rather self-explanatory - beautiful mountains and water that symbolize a clear and ecological product. The colour scheme is not too wide. We can only see the colourful bottles, the rest of the background is done in different shades of green and blue. Green is considered to be the colour of nature that has the ability to control and comfort our emotional state. Being in the center of the color spectrum it performs the role of a life balance (Colour Affects). Green is often used to depict and strengthen the fact that the product is fresh and natural (How colours manipulate your emotions). The application of the dark blue colour is justified by the fact that it is the only colour that is used to describe the purity of water and its freshness. All of these attributes can be noticed and seen in the advertisement. From the structural and pragmatic points of view this advertisement is national, printed, commercial, and lightly segmented.

The second advertisement (picture 2) is the ad of the mineral and still water for children. We can again see the usage of green and bluish colours to depict the mountains that, in its turn, creates the feeling of freshness and natural origin. But, unlike the previous advertisement, we can see more colours here. There are different animals drawn in orange, pink, blue and purple. We can also see the verbal message - a slogan that is written in green, red and blue colours. The message says: "Natural drinking water for kids from the first days of their life". The iconic symbols underneath it $-0+-$ duplicate the same information. The text is written with the help of different fonts and is a bit chaotic, which creates the feeling of fun and a friendly effect. If we look again at the selection of a colour scheme, we can say that the red colour, having the longest wave, has a very strong effect on humans' perception, quickly attracting their attention and stimulating them to act. As to the blue colour, psychologists consider it to be one of the most favourite color in the world (Colour Affects). They also believe that it enhances to the mental processing and arises a feeling of purity. The choice of the pink colour can be explained by the fact that it nourishes and, at the same times, calms people (Colour Affects). Besides, if we take into consideration some gender peculiarities, we will find out that this colour is considered to be a strongly female colour (which is important for the advertisements for children

as these are the mothers who mainly choose and buy products for their kids). Orange has a similar effect as the red colour, but it stimulates emotional as well as physical reactions. It also creates the feelings of warmth, happiness, and protection. One more important feature is the application of the pictograms of animals, depicted sitting next to the bottles and on the bottles. The name of the water-мориинка - is very interesting as well, because it is a derivative from the name of the water for adults-мориинська - and has a diminutive meaning. So, we can say that the smart combination of non-verbal elements (colours, iconic elements, layout) and verbal elements makes this multimodal advertisement very powerful and appealing. This advertisement is also national, commercial, printed, and medium segmented.

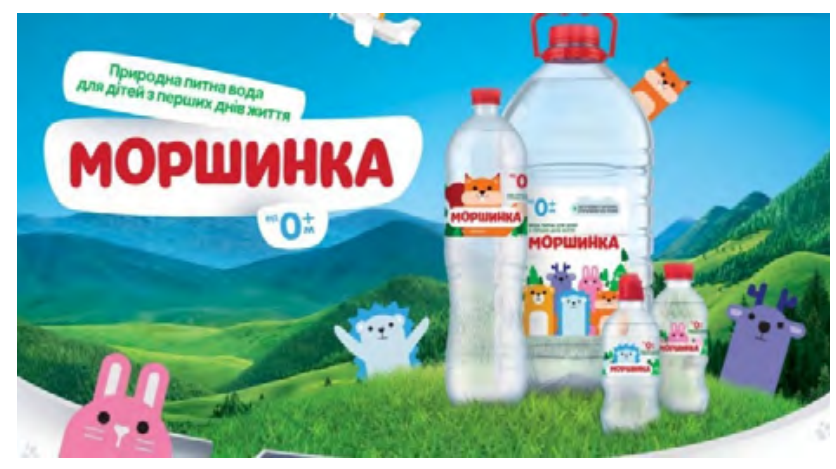

Picture 1

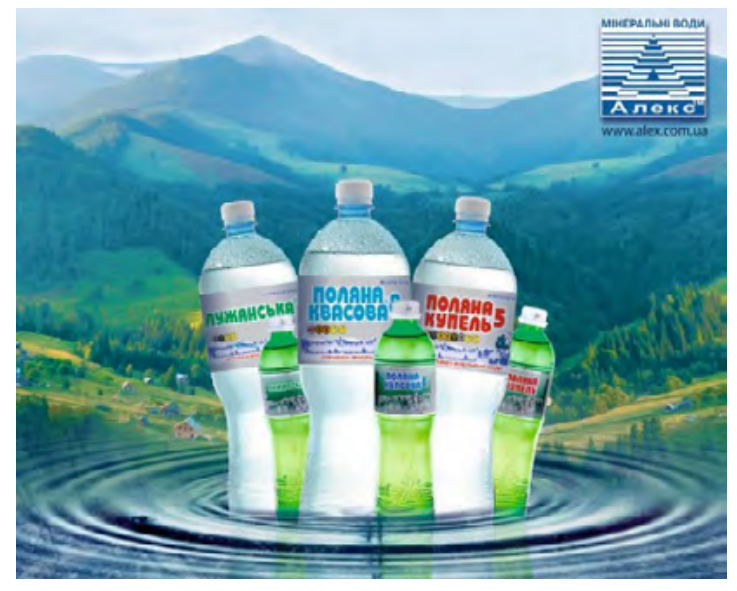

Picture 2

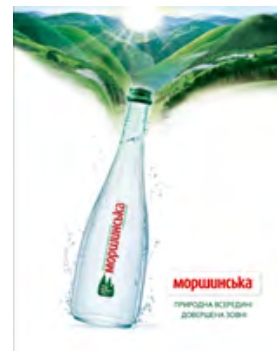

Picture 3

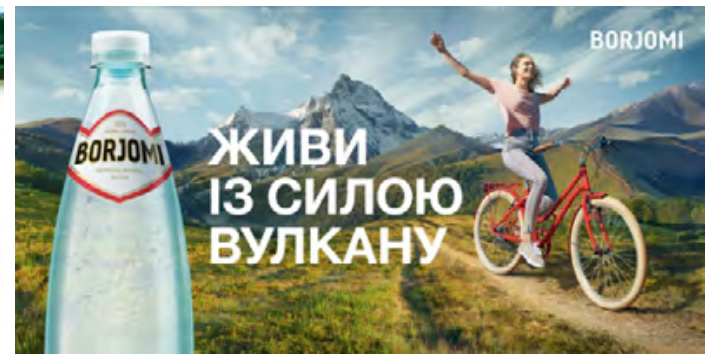

Picture 4 


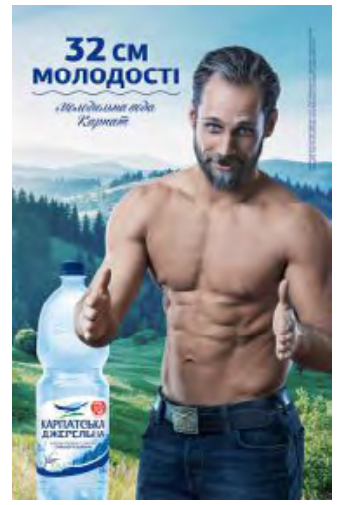

Picture 5
Another advertisement (picture 3) promotes the same mineral water Мориинська (Morshynska) but for adults. In this advertisement we can see a very interesting correlation of verbal and non-verbal elements, when the text message dublicates the image "Natural inside, perfect outside". A picture of green, fresh and pure mountains seems to fall into the bottle, as the picture is created in the shape of water and the image of a bottle design is believed to be "perfect". A green colour in combination with white one, creates the feeling of pureness, cleanness and freshness. On the basis of D. Bezlatnyi classification, this advertisement is national, commercial, printed, and lightly segmented.

Picture number 4 is an advertisement of a very popular and well-known mineral water-Borjomi, the name of which is repeated twice. The verbal message - Live with the power of a volcano encourages consumers to be healthy and strong by having a healthy life style, driving a bike, being active and drinking pure water. The meaning of the verbal message is intensified by the images of mountains, green grass and a young woman on a bike whose body language tells us about her physical power and freedom.
The last example (picture 5) is an advertisement of the mineral water Карпатська джерельна, in which a very strong, relatively young man is depicted in front of the beautiful mountain range, showing his thumps up. The perfect figure of the depicted man proves the positives of the advertised mineral water. The verbal messages - 32 см молодості $(32 \mathrm{~cm}$ of уоит). Мінеральна вода Kарпат - are written in blue, and create the feeling of pureness and cleanness. The textual message - $32 \mathrm{~cm}$ молодості - indicates that a $32 \mathrm{~cm}$ bottle will make you healthy and look like the man in the picture.

Conclusions. So, we can say that verbal and non-verbal elements are used in all types of multimodal advertising. Non-verbal means, correlating with the verbal elements, either intensify, or repeat and complete the meaning of the verbal messages. The variations of fonts (cursive, underlined, bold), sizes of letters, their capitalization and colouring help to make the texts bright and memorable. In the analyzed examples, the majority of copywriters used the images of mountains and water to demonstrate that their product is fresh, clear and natural. The chosen colour scheme includes blue, green and white colours as it is required by the theme of the advertisement. All of the chosen advertisements depict the closeness to nature, life balance, calmness, and purity. As they were created to promote a very popular and essential product - mineral water - they are national, direct, lightly or medium segmented and commercial.

\section{BIBLIOGRAPHY}

1. Барт Р. Текстуальний аналіз «Вольдемара» Е. По. Слово. Знак. Дискурс: Антологія світової літературнокритичної думки ХХ ст .: зб наук. пр. Львів : Літопис, 2002. С. 497-524.

2. Безлатный Д. В. Психология в рекламе: исскуство манипуляции общественным сознанием. Москва : ООО «Ваш полиграфический партнер», 2011. 236 с.

3. Валгина Н. С. Теория текста. Москва : Логос, 2003. 280 с.

4. Лютянська Н. І. Мас-медійний дискурс: типологічні та структурно-організаційні особливості. Наукові записки НДУ ім. Миколи Гоголя. Сер. Філологічні науки. 2014. Кн. 2. С. 136-140.

5. Морозова І. Б. «З’їж мене!»: слоган як ключовий елемент англомовного рекламного повідомлення. Актуальні проблеми романо-германської філологї̈ та прикладної лінгвістики. 2017. Вип. 2 (15). С. 67-72.

6. Поляков В. А. Анализ становления мирового рекламного рынка и рекламы в России. Маркетинг в России и за рубежом. 2006. № 2. URL: https://dis.ru/library/516/25952/ (Last accessed: 25.11.2020).

7. Сукаленко Н. И. Отражение обыденного сознания в образной языковой картине мира. Киев : Наук. думка, 1992. $164 \mathrm{c}$.

8. Colour Affects. Psychological Properties of Colours. URL: http://www.colour-affects.co.uk/psychological-properties-of-colours (Last accessed: 26.11.2020).

9. How Colors Manipulate Your Emotions. URL: http://www. Sommer-sommer.com/brainfacts/how-colors-manipulateyour-emotions/ (Last accessed: 26.11.2020).

10. Messaris P. M. The Role of Images in Advertising. London, New Dehli : SAGE Publications, 1996. 296 p.

\section{REFERENCES}

1. Bart, R. (2002). Tekstualnyi analiz "Voldemara” E. Po [Textual analysis of "The Facts in the Case of M. Valdemar" by E. Poe]. In. M. Zubytska, ed., Slovo. Znak. Dyskurs: Antologiya svitovoi literaturno-krytychnoi dumky XX st. [Word. Sign. Discourse: Anthology of the world's literature and critical thought of XX century]. Lviv: Litopys, pp. $497-524$ [in Ukrainian].

2. Bezlatnyi, D. V. (2011). Psihologiya v reklame: iskustvo manipuliacii obshchestvennym soznaniem [Psychology in advertising: the art of manipulation of the public consciousness]. Moskva: "Vazh poligraficheskii partner" [in Russian]. 
3. Valgina, N. S. (2003). Teoriya teksta: uchebnoe posobie [Theory of text: study manual]. Moskva: Logos [in Russian].

4. Liutianska, N. I. (2014). Mass-mediinyi dyskurs: typologichni ta strukturno-organizaciini osoblyvosti [Mass-media discourse: typological, structural and organizational peculiarities]. Naukovi zapysky NDU im. Mykoly Gogolia. Ser. Filologichni nauky [Scientific notes of NDU named after M. Gogol. Section "Philology"]. Nizhyn, pp. 136-140 [in Ukrainian].

5. Morozova, I. B. (2017). “Z'izh mene!” Slogan yak kliuchovyi element anglomovnogo reklamnogo povidomlennia [“Eat me!" Slogan as a core element of an English advertisement]. Aktualni problemy romano-germanskoi filologii ta prykladnoi lingvistyky [Modern problems of Romance-Germanic philology and Applied Linguistics]. Chernivtsi: Vydavnychyi dim "Rodovid", pp. 67-72 [in Ukrainian].

6. Poliakov, V. A. (2006). Analiz stanovleniya mirovogo reklamnogo rynka i reklamy $v$ Rosii [Analysis and stages of development of the world advertising market in Russia]. Marketing $v$ Rosii $i$ za rubezhom [Marketing in Russia and abroad]. URL: https://dis.ru/library/516/25952/ [in Russian].

7. Skukalenko, N. I. (1992). Otrazhenie obydennogo soznaniya v obraznoi yazykovoi kartine mira [Reflection of everyday consciousness in the figurative map of the world]. Kiev: Naukova dumka [in Russian].

8. Colour Affects. Psychological Properties of Colours. URL: http://www.colour-affects.co.uk/psychological-properties-of-colours.

9. How Colors Manipulate You Emotions. URL: http://www. sommer-sommer.com/brainfacts/how-colors-manipulate-your-emotions/.

10. Messaris, P.M. (1996). The Role of Images in Advertising. London, New Dehli: SAGE Publications.

\section{ILLUSTRATIVE SOURCES}

1. URL: https://molbuk.ua/news/85562-liky-darovani-karpatskoyu-pryrodoyu-na-pravakh-reklamy.html (Last accessed: 26.11.2020).

2. URL: https://sostav.ua/publication/morshinskaya-vypustila-vodu-dlya-samykh-malenkikh-79205.html (Last accessed: 25.11.2020).

3. URL: https://window.unian.ua/1984009-morshinska-onovila-dizayn-plyashki.html (Last accessed: 24.11.2020).

4. URL: http://www.adme.ua/creativity/novij-shlyah-borzhomi-banda-129025/ (Last accessed: 12.11.2020).

5. URL: https://kmw.com.ua/news/karpatska-dzherelna-molodylna-voda-karpat/ (Last accessed: 26.11.2020). 